\title{
NET STRUCTURE OF SUBJECT-TO-SUBJECT RELATIONS IN THE MANAGEMENT OF THE SYSTEM OF ADMINISTRATIVE SERVICES PROVISION
}

\author{
Yulya Danshina ${ }^{1}$ \\ University of Customs and Finance, Ukraine \\ Igor Britchenko² \\ State Higher Vocational School Memorial of Prof. Stanislaw Tarnowski in Tarnobrzeg, Poland
}

\begin{abstract}
The purpose of the work is to form the net structure of management of the system of administrative services provision on the basis of implementation of subject-to-subject interactions between state sector and civil society. Methodology. The methodology basis for the investigation is the abstract-logical analysis of theoretical and methodological backgrounds for management of relations and interactions. For the theoretical generalization and formation of net structure, there are used scientific recommendations of Ukrainian scientists regarding the necessity to implement subject-to-subject relations in the system of administrative services provision. Results. The investigations allowed confirming that the hierarchical structure of the state governance system does not give an opportunity to implement equal interaction between a subject of provision and a subject of an appeal as these relations have one - way communication and the feedback channel has a formal character. Moreover, the civil society is not considered by state sector to be a source of methods and ways to develop the system of state governance, in particular, the management system of administrative services provision. Practical meaning. The net structure of management will allow implementing the subject-subject relations in the system, under which the actions of the subject of provision - that means state sector - will be directed to the realization of rights and interests of the subjects of appeal. In their turn, apart from the performance of all legislative responsibilities that they should perform, they can carry out activities directed to the development of management activity in the system of administrative services provision and the whole system of state governance as an integral system of management. Meaning/Distinction. The provided model of the net structure will allow involving citizens in the processes of state governance and increasing the impact of the civil sector during the making of state and management decisions and, as a result, to confirm subject-to-subject positions in the relations.
\end{abstract}

Key words: management, system, net management, hierarchical management, subject of provision, subject of appeal.

JEL Classification: H70, H73, H79

\section{Introduction}

During the last twenty years, Ukrainian independent state is trying to form high-quality, clear, effective, decentralized management of the system of providing administrative services. However, the necessity of building powerful interrelations between the civilian sector and the state sector stipulates the search for such a management model that would, on the one hand, correspond with the spirit of modernity, on the other hand - would not destroy the unity of three principles of the native system of state administration permanence, anonymousness, and neutrality (Mohov,
Oujen, 2000). Therefore, we consider that an attempt to interpret, sift, and analyse the specificity of the network structure of the management of the system of providing administrative services and the process of interaction between the "subject of applying" and the "subject of providing" through the category "subjectsubject relations" is relevant and has a certain potential of scientific novelty and innovative recommendations for their improvement. The necessity of the above is reflected in domestic studies of the mechanisms of state administration (Nyzhnyk, Lelikov, Mosov, 2001), in which it is emphasized that this is "... the relationship

Corresponding author:

${ }^{1}$ Department of Public Administration and Customs Administration, University of Customs and Finance.

E-mail: danyulya@i.ua

${ }^{2}$ Faculty of Economic and Technical Sciences, State Higher Vocational School Memorial of Prof. Stanislaw Tarnowski in Tarnobrzeg.

E-mail: ibritchenko@gmail.com 
between two interconnected processes, when the first of them is a general one, and the second is specific, intended to realize the first...”

\section{The hierarchical structure of subject-object relations}

The existence of systems with different patterns of construction, functioning and developing under different conditions, varying in the degree of structure ordering and depth of cognition (Nechiporenko, 1977) led to an impressive number of definitions of the term "system".

In the encyclopaedia of state administration (Surmin, Nadolishnii, 2011) "system" is considered as a set of elements, characterized by the structure, connections and functions that ensure its intentional development as a whole. System is the opposite of chaos, disorder, disorganization; is characterized by such features as aggregate, plural number, integrity, orderliness, organization, hierarchy; is a combined set of elements (subsystems), which are expectedly connected with each other and with the objects of the environment; has different scales (micro-, macro-, meta-, mega-system), degree of complexity (simple, complex), nature (social, technical, physical, biological, chemical), openness form (open, closed), origin (artificial, natural), organization and adaptability; it is a complex of megasystems, subsystems, elements, components and their properties, the interaction between which predetermines the appearance of a qualitatively new integrity (Mochernyi, 2006).

Summarizing the abovementioned definitions, should be noted the lack of a universally recognized scientific approach to the definition of the term "system" and the presence in the existing interpretations of similarities, the main features in its definition, which must be taken into account in the course of the research, namely: system is a process of interaction of its interconnected components between each other and with the environment; system has a certain goal the achievement of a qualitatively new state, level of integrity, and so on; system is characterized by structural elements (public institutions, people, subsystems, etc.) and management processes that are aimed at increasing the level of orderliness, organization of these elements and interaction with socio-economic, political, and other systems.

Considering the dichotomous nature of the concept of the term "system", on the one hand, as an indicator of the reality of existing phenomena, on the other hand, as a method of studying and objectifying of phenomena, that is, as a subjective model of reality (Korikov, Pavlov, 2008), in our study the most decentish is the approach of N. Buslenko (1978), which lies in identifying the main characteristics that define a certain component as a system. To such characteristics, in particular, refer:
- presence of a certain amount of interconnected subsystems, functions that they realize, and directions for achieving specified goals of functioning;

- permissibility of system dismembering into subsystems, functioning of which is aimed at the realization of the system goal;

- obligatory presence of: management, extensive information network, dynamic information flows;

- interaction with the environment under all conditions.

The system of providing administrative services consists of the state sector, which includes the providers of administrative services, those are, as a rule, executive authorities, and non-state sector - the recipients of administrative service, those are individuals and legal entities. Taking into account the provisions of the Law (Pro administratyvni poslugy, 2012), regulating the sphere of providing administrative services, which determinates the provider as a "subject of providing" and the recipient - as a "subject of applying", thereby puts in the structure of the system of providing administrative services "subject-subject relations".

Supporters of the integration of the "feedback" defend the reasonability of organization of such relations between the elements of the socio-economic system (Petrenko, Dzvinchuk, Nemchuk, 2012), however, studies of this phenomenon in the system of providing administrative services are limited to subject-object relations, that is, on a unilateral basis, in which: the subject of management or the management system is the subject of providing, that is, the state administrative authority, the subdivision of administrative authority or the designated person, suggesting and accepting state and administrative decisions concerning the implementation of the controlled impact on subordinate objects of management or regulation of certain processes and relationships. And the object of management or a managed system is the subject of applying, that is, a society as a whole, processes, relations in various fields, spheres of activity, branches of public life, organizations, associations on which the activities of the relevant subjects of management are directed; a set of connections of a system of management relations in their interaction.

According to the Constitution of Ukraine (2016), there are three types of authorities, directly providing state administration and state-management activity aimed at providing administrative services:

- central - Verkhovna Rada of Ukraine, Cabinet of Ministers of Ukraine, ministries and institutions, the status of which is considered to be state;

- zonal - regional, district, city state administrations of Kyiv and Sevastopol, Autonomous Republic of Crimea, and territorial bodies of central executive authorities;

- local - rural, settlement, city, district councils, including Kyiv and Sevastopol, Autonomous Republic of Crimea councils. 
The interaction of these authorities is directed, first of all, to the realization of interaction in the system of providing administrative services of Ukraine as an activity on ensuring the realization of the rights and freedoms of citizens.

In our study, we rely on the simultaneous use of terms of state and public administration authorities depending on the subject-matter of the represented context.

The structure of the state administration of the system has a pronounced hierarchy (Figure 1), where a higher hierarchical level affects the lower level, despite the partial delegation of management functions. Relations between levels are dependent on the laws of subordination; levels are unequal and interact with each other according to the principle of "powersubordination" (Oslavskyi, 2009).

It also should be pointed out that, despite the generally widespread understanding that the process of improving the system of providing administrative services is closely connected with the opinion and attitude of subjects of applying to the activity processes of the subjects of the providing, most theoretical models, practical recommendations, and methodological developments on the formation and improvement of the system is exclusively on the subject-objective positions, and the feedback in these relations is considered exclusively as a channel for complaints and negative reviews by citizens concerning the functioning and performance of their duties by subjects.

As a rule, goals, tasks, functions, methods, levers, tools, incentives, motives, structures, and so on are chosen as a topic for the research, improvement and modernization. Thus, in writing of scientists I. Koliushko (2009) and V. Tymoshchuk (2015), the organizational and legal grounds of administrative services during the period of administrative reform are examined. The authors believe that the system of providing administrative services in Ukraine is non-clear, irrational, and is one that does not fully take into account the interests of Ukrainian society.
Scientists emphasize the need for creating an effective and high-quality procedure for providing administrative services to citizens because exactly for the quality of the provided services each person assesses the state's concern for him.

V. Bakumenko, Yu. Kalnish, S. Kravchenko, and other scientists are convinced (2005) that the main tasks of administrative reform are the formation of an effective system of public administration; the providing of quality services to citizens at a level corresponding to European standards; optimal usage of public funds and the ability to react to socio-economic and foreign policy provocation timely and adequately.

A. Obolenskyi (2005) considers as one of the main tasks of the Ukrainian state the providing quality administrative services to civil society. The scientist focuses on the need for detailed study of the statutory and legal regulating of the mechanism of state administration of the system of providing administrative services, their list, cost, criteria for assessing the quality of their providing, etc.

Researchers A. Lipentsev and Yu. Zhuk assert that the system of providing administrative services in Ukraine requires further improvement and legal response, because, first of all, it depends on the effectiveness of state administration authorities, state servants, and officials who are directly involved in the providing of administrative services (2015).

During the developing of the formation concept of the system of providing administrative services by state administration authorities in Ukraine, T. Burenko (2011) defines such principles for further improvement: - measuring the effectiveness of the state administration authorities activity, based on the results of the developed correspondent criteria of resulting quality for each state service;

- the work of state administration authority for the needs of the subjects of applying;

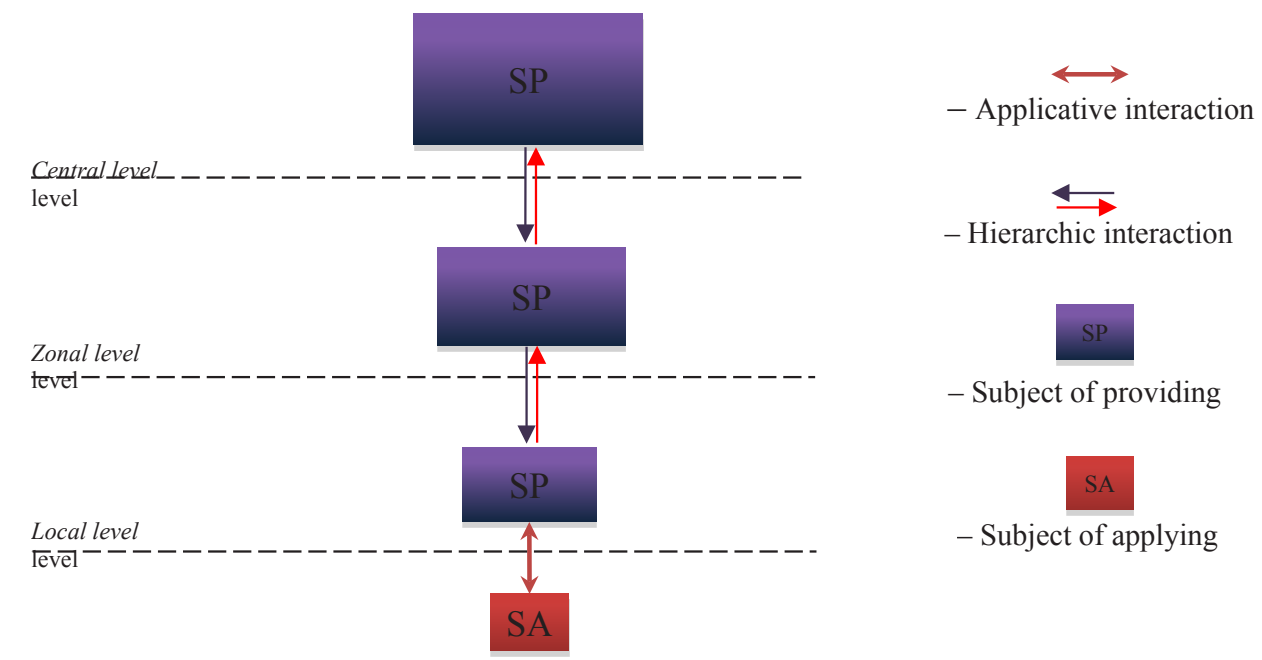

Fig. 1. The hierarchical structure of management of subject-object relations 
- maximum satisfaction with legal requirements of recipients of subjects of applying at minimum costs;

- application of audit elements of activity of the state administration authorities;

- activation and consolidation of state, private and public sectors in the development and realization of policies on providing of administrative services by state administration authority.

Existing scientific researches in Ukraine reflect the content of the system of providing administrative services as a complex socio-economic system consisting of a set of elements and relationships of subject-object relations that are regulated by statutory and legal acts in the state-administration activity of the subjects of management, activity of which is aimed at satisfying the public interest in reviewing the application of an individual or legal entity and issuing an administrative act to ensure the rights and legal interests and/or to implement certain statutory duties.

\section{The network structure of subject-object relations}

It is quite obvious that a symmetrical model is also up for consideration, in which the subject of applying acts as a subject of management and the management system, and the subject of providing - as the object of management and the controlled system, the essence of which is to be thoroughly studied in order to identify opportunities for improving and modernizing processes of state administration, by the participation of the subject of applying in the processes of state administration and influence on the adoption of managerial decisions.

A network structure is a set of interrelated subjects, the specific content of which depends on the nature of the system. The network form allows adapting quickly to external dynamic conditions. According to the opinion of M. Castells, the society is in the dissemination of the network organizational culture, which up to now has not claimed to be the dominant role but in terms of efficiency is higher than the hierarchical one. "The networks constitute a new social morphology of our societies and the spread of "networked" logic largely affects the course and outcome of the processes associated with production, everyday life, culture, and power" (Stanovlenie obshhestva setevyh struktur).

Under this approach, not only state structures but also civil society should have a right to receive and analyse information on state-management activity, participate in the adoption of relevant decisions, and not only control their implementation and monitor the quality of administrative services but also introduce and realize proposals for improving administration activity.

Represented information demonstrates obvious that in order to have the state administration system, which corresponds to an adequate state in relation to the modern international tendencies of the information society, it is necessary to promote the rise and construction of civil society institutions that adequately ensure the clearness of the activity of state administration authorities, protect public interests and would be able to realize their rights and freedoms.

Despite its importance, the Constitution of Ukraine does not contain the definition of this term; only some of its elements are reflected, such as private property, market economy, human rights, political pluralism, freedom of speech, multiplicity of parties, etc., however, the Constitution (2016) contains the fundamental principles of "civil society", for example, Art. 8 enshrined the rule of law.

The construction of a civil society in Ukraine will allow the relationship between the subject of applying and the subject of providing to reach a new level, primarily characterized by the quality of the providing of administrative services by state administration authorities. Prominent Ukrainian scientist B. Kistiakovskyi long before the beginning of the state administration reform in Ukraine noted that "the basic component of the system of human rights and freedoms is the individual's right to positive services from the state" (1998). However, only in 2009-2010 this assertion acquires significance and becomes the fundamental principle of the modern system of state administration in Ukraine.

The paradigm of modern state administration being under reform is perfectly considered by the native scientist V. Averianov, representing it as an "integral set of coordinated measures aimed at significantly increasing the level of controllability of vital processes in society through scientifically based creation of an effective mechanism of state administration, development of administrative legislation, improvement personnel, informational-technical and financial-economic support of organization of executive government and local self-administration" (Averjanov, 2004).

From modern approaches to the content of the term "civil society" interesting are the following:

- the society of self-expression of free active citizens and on the voluntary basis of formed associations and organizations that do not pursue commercial goals, which are not dependent on direct intervention and regulation by the state sector and the business sector, as well as other external factors (Easton, 1965);

- one of the guarantors of observance of human rights, the totality of public relations of an integral state but beyond the power-state and commercial structures (Barenbojm, 2010).

Under this approach, the system of providing administrative services remains a complex socioeconomic system, but consists of a set of elements and interconnections of subject-object relations, in which the activity of subjects of applying, civil society, and just interested individuals is aimed at searching for methods and ways to improve the system of state administration. 


\section{Hierarchic and network structure of subject-subject relations}

A quite difficult problem is the connection of elements $\rightarrow$ subsystem $\rightarrow$ system into an integrated model that would adequately describe the system functioning taking into account the interaction of its various subsystems. This is connected both with the complexity of the state administration system, system of providing administrative services and with the incomplete study of all the laws of their functioning.

The management of the system of providing administrative services, which is, on the one hand, connected by the communication channels with many other systems and is a subsystem of the state administration system, on the other hand - is itself a complex system characterized by heterogeneous infrastructure and requires a rethinking of the ways of improvement, the transformation of which leads to significant transformations in social and economic relations, which naturally affects its structure, which becomes more complex, because the network is superimposed on the hierarchical structure, forming a complex hierarchical-network structure (Fig. 2).

The complexity of the system is determined by the number of levels of system partitioning into subsystems, the uniqueness of the elements that form them, the set of functions performed by them, the number of interactions with other, multiplicity, and heterogeneity of reactions to the influence of external and internal factors, all this indicates the relativity of the concept of complexity and blurring of the "complexity limit" (Barabási, 2007).

In this way, under a hierarchic network structure, we mean a system, in which each subsystem at a certain level is a system, in other words, a network subnet. However, the above level, except influencing the underlying level, interacts with it, by acquiring new properties from the network subnet, which they did not have in the isolated state, the possession of which allows the system to be endowed with new, significant qualities (Volkova, Denisov, 2014).

Management of the system of providing administrative services, which has a hierarchical-network structure, we consider as more difficult than hierarchical. However, such a structure is temporary, because it is considered by us, exclusively as a transitional form to the network structure of the system of providing administrative services, which assumes a simpler form than a hierarchical.

\section{The network structure of subject-subject relations}

The key factor in the availability of subject-subject relations in management (Figure 3) is the receipt from civil society of not only the quality requirements of

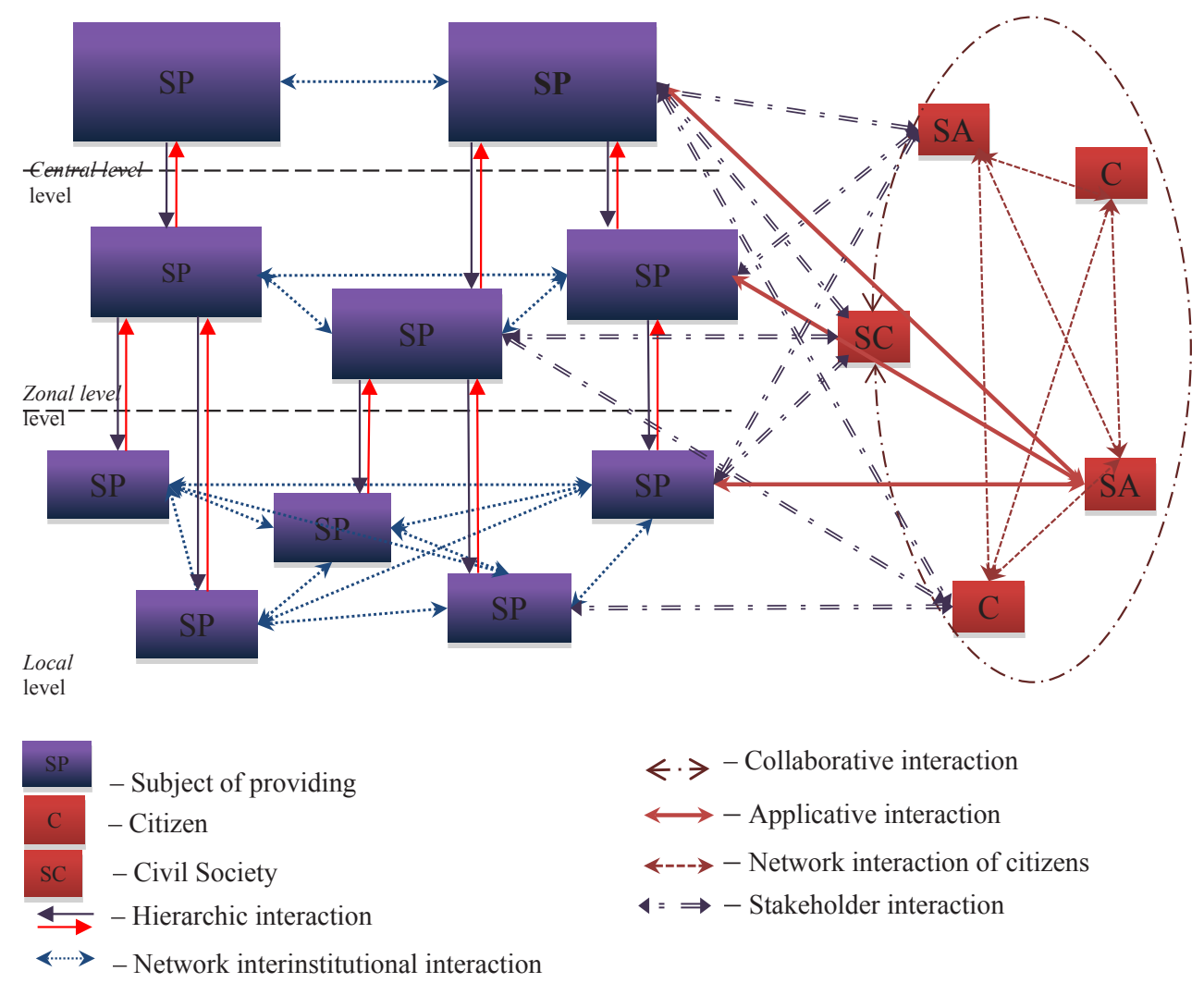

Fig. 2. Hierarchic and network structure of subject-subject relations 


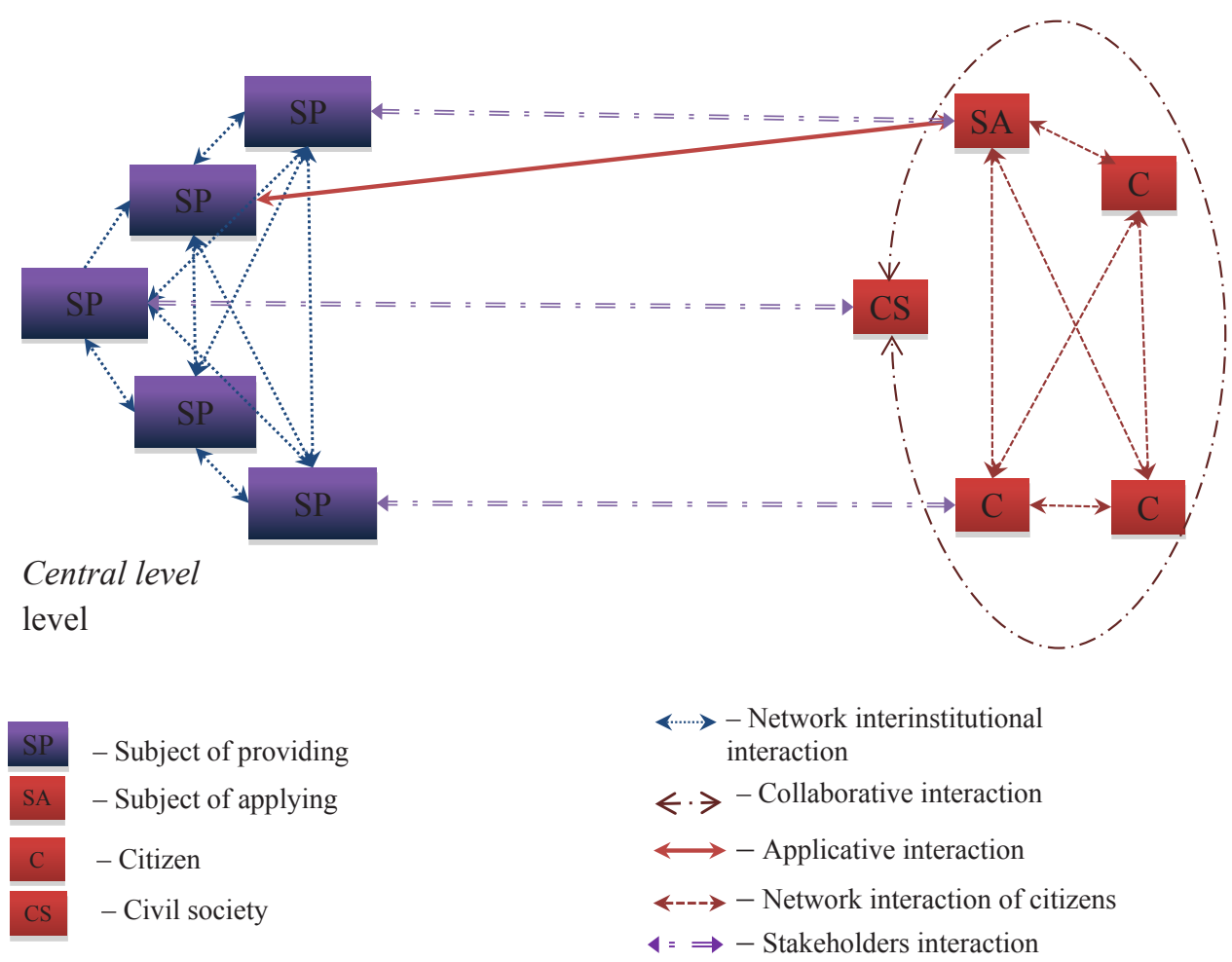

Fig. 3. The network structure of subject-subject relations in the management of the system of providing administrative services

management processes, the quality of providing administrative services, information as responses to subjects of treatment, participation in voting, but also knowledge and opportunities to implement ways to improve the management of the system of providing administrative services.

An attempt to reveal the content of the process of interrelations between the "subject of applying" and the "subject of providing" was made by D. Sukhinin. However, the proposed scheme interpretation of "... the process of ensuring the quality of activity for the providing of municipal services", which took into account the requirements of the "methodology for describing processes IDEFO” (Popov, 2011), despite the importance and general character, does not reveal the essence of the process itself. The scheme of the researcher, like in most domestic studies of various possibilities and aspects of improving public administration, "subject-subject relations" uses a theoretical axiom as a defined givenness.

Taking into account that subject-subject relations will allow the system to determine "... deviations of the system from a certain state for the formation of a control action" (Hlushkov, 1973), but “... the existence of channels for the receiving by the authorities information about the assessment of certain aspects of its activities by the population, public organizations, business circles, other government structures" (Kovalevich, 2008), makes it possible to assert that the participation of citizens in the processes of state administration and the influence on the adoption of managerial decisions will allow the processes of self-organization, self-regulation, and selfmanagement in social systems to become possible.

Exactly in this regard, the formation of the network structure of subject-subject relations in management is the priority task of any participant and subjects of the system of providing administrative services. After all, “... the system of state administration is integral, consisting of certain interconnected subsystems, a set of elements that form a certain unity, integrity, and function in the interrelations and interconnections among themselves" (Bakumenko, Beznosenko, Varzar, Knjazev, Kravchenko, Shtyk, 2002).

\section{Conclusions}

The current state of management of the system of providing administrative services is analysed and it is determined that most of the domestic scientific research is devoted to the study of subject-object relations, despite the fact that the system of providing administrative services has a subject-subject structure, and management can be viewed in a symmetrical direction. Taking into consideration that the system of state administration is a coherent system, it is proposed to implement the network structure of subject-subject relations, in which the result of interaction, on the one hand, will be activity aimed directly at the providing 
administrative services and all the processes associated with this activity, namely, ensuring quality, transparency etc., on the other hand - activity aimed at improving the system of state administration. It is quite obvious and logical that the further direction of our research should be the tasks of developing recommendations and their practical implementation in state and management activities.

\section{References:}

Averjanov, V. B. (ed.) (2004). Administrativnoe pravo Ukrainy. Obshhaja chast. Administrativnoe pravo Ukrainy. Akademicheskij kurs. Kiev: Juridicheskaja mysl.

Bakumenko, V. D., Beznosenko, D. O., Varzar, I. M., Kniazev, V. M., Kravchenko, S. O., Shtyk, L. H. (2002). Derzhavne upravlinnia [State Governance] (eds. Kniazev V. M., Bakumenko V. D.). Kyiv: UADU.

Bakumenko, V. D., Hohin L. M., Koziura I.V. Kravchenko S. O., Kalnysh Yu. H., Shtyka L. H. (2005). Yevropeiski oriientyry administratyvnoho reformuvannia v Ukraini [European benchmarks for administrative reform in Ukraine]. (eds. Bakumenko V. D., Kniaziev V. M.). Kyiv: NADDU.

Barabási, A.-L. (2007). The architecture of complexity. IEEE Control Systems Magazine, vol. 27, no. 4, pp. 33-42.

Barenbojm, P. D. (2010). Pravovoe gosudarstvo kak partner grazhdanskogo obshhestva: k 150-letiju opublikovanija koncepcii "Gosudarstvo kak proizvedenie iskusstva". Zakonodatel'stvo i jekonomika, no. 9.

Burenko, T. O. (2011). Formuvannia systemy nadannia administratyvnykh posluh orhanamy derzhavnoi vlady v Ukraini [Formation of the system of providing administrative services by state authorities in Ukraine] (Avtoref. dys. kand. nauk z derzh. upr.). Natsionalna akademiia derzhavnoho upravlinnia pry Prezydentovi Ukrainy. Kyiv.

Buslenko, N. P. (1978). Modelirovanie slozhnykh sistem [Simulation of complex systems]. Moskva: Nauka.

Easton, D. A. (1965). Framework for Political Analysis. London; Sydney; Toronto; New Delhi; Tokyo.

Hlushkov, V. M. (ed.) (1973). Entsyklopediia kibernetyky [Encyclopedia of Cybernetics] (Vol. 2). Kyiv: Holovna redaktsiia Ukrainskoi radianskoi entsyklopedii.

Kastels Manuel. (n.d.) Stanovlenie obshchestva setevykh struktur [The formation of a society of network structures]. Available at http://podelise.ru/docs/index-25213440-1.html (accessed 03.9.2017).

Kistjakovskij, B. A. (1998). Filosofija i sociologija prava (eds. Davydov Ju.N., Sapov V. V.). Sankt-Peterburg : Rus. Hristian. gumanitar. in-t.

Koliushko, I., Tymoshchuk, V., Banchuk, O., Bekeshkina, I. (2009). Koruptsiini ryzyky nadan nia administratyvnykh posluh ta kontrolno-nahliadovoi diialnosti v Ukraini [Corruption risks of providing administrative services and control and supervision activities in Ukraine]. Kyiv: Moskalenko O.M.

Konstytutsiia Ukrainy (zi zminamy i dopovnenniamy) (2016). Retrieved from: http://zakon4.rada.gov.ua/laws/ show/254k/96-vr (accessed 17 December 2017).

Korikov, A. M., Pavlov, S. N. (2008). Teoriya sistem i sistemnyy analiz [Theory of systems and system analysis]. Tomsk: Tomskiy gosudarstvennyy universitet sistem upravleniya i radioelektroniki.

Kovalevich, I. P. (2008). Teoretychni zasady zabezpechennia zvorotnoho zviazku v derzhavnomu upravlinni [Theoretical principles of providing feedback in public administration]. Derzhavne budivnytstvo [State building], 2. Retrieved from: http://www.kbuapa.kharkov.ua/e-book/db/2008-2/doc/1/15.pdf (accessed 12.11.2017)

Lipentsev, A. V. (2015). Administratyvni posluhy v Ukraini: poniattia ta sutnist [Administrative Services in Ukraine: Concepts and Essence] (eds. Lipentsev A. V., Zhuk Yu. M.). Efektyvnist derzhavnoho upravlinnia [Effectiveness of public administration], vol. 42. Lviv : LRIDU NADU, pp. 140-149.

Mochernyi, S. V. (ed.) (2006). Ekonomichnyi entsyklopedychnyi slovnyk [Economic Encyclopedic Dictionary] (Vol.1-2). Lviv: Svit.

Mohov, V.P., Oujen, N. (2000). Gosudarstvennaya sluzhba i byurokratiya. Rossiya i Britaniya v poiskakh dostoynogo pravleniya. Perm'.

Nechiporenko, V. I. (1977). Strukturnyy analiz sistem [Structural analysis of systems ]. Moskva: Sovetskoe radio. Nyzhnyk, N., Lelikov, H., Mosov, S. (2001). Pro spivvidnoshennia katehorii «protses» i «mekhanizm»ta yikh vykorystannia v upravlinskii diialnosti orhaniv vykonavchoi vlady [On the relationship between the categories "process" and "mechanism" and their use in the management activities of executive authorities]. Visnyk derzhavnoi sluzhby Ukrainy [Bulletin of the Civil Service of Ukraine], no. 3, pp. 80-87.

Obolenskyi, Yu. (ed.) (2005). Derzhavne upravlinnia ta derzhavna sluzhba: slovnyk-dovidnyk [Public administration and public service: dictionary-directory]. Kyiv: KNEU.

Oslavskyi, M. I. (2009). Vykonavcha vlada v Ukraini: orhanizatsiino-pravovi zasady[ Executive power in Ukraine: organizational and legal principles]. Kyiv: Znannia.

Petrenko, V. P., Dzvinchuk, D. I., Nemchuk, O. V. (2012). Teoretychna reinterpretatsiia sutnosti i dii zvorotnykh zviazkiv yak osnovy intehratsiinykh protsesiv $\mathrm{v}$ upravlinni sotsialno-ekonomichnymy systemamy [Theoretical reinterpretation of the essence and effect of feedback as the basis of integration processes in the management of socio-economic systems] (eds. Pererva P. H., Savchenko O. I., Tovazhnianskyi V. L.). Menedzhment, marketynh ta intelektualnyi kapital $\mathrm{v}$ hlobalnomu ekonomichnomu prostori [Management, marketing and intellectual capital in the global economic space]. Kharkiv: «Tsyfrova drukarnia № 1», pp. 209-220. 
Popov, S. M. (2010). Naukova paradyhma subiekt-subiektnoho upravlinnia v umovakh suchasnoho kontynuumu [Scientific paradigm of subject-subject control in the conditions of the modern continuum]. In H.V. Voronkova (Red.). Humanitarnyi visnyk Zaporizkoi derzhavnoi inzhenernoi akademii [Humanitarian Bulletin Zaporizhzhya State Engineering Academy], no. 43. Zaporizhzhia : ZDIA, 166-175.

Pro administratyvni posluhy. Zakon Ukrainy [About administrative services. Law of Ukraine] № 5203-VI (2012). Sukhinin, D. V. (2005). Protsesnyi pidkhid do orhanizatsii diialnosti z nadannia munitsypalnykh posluh [Process approach to the organization of municipal services] (eds. Sukhinin D. V., Mamatova T. V.). Derzhavne upravlinnia: teoriia ta praktyka [Public Administration: Theory and Practice], vol. 2. Retrieved from: www.academy.gov.ua/ej/ ej2/.../05sdvnmp.pdf (accessed 22.10.2017).

Surmin, Yu. P., Nadolishnii, P. I. (eds.) (2011) Metodolohiia derzhavnoho upravlinnia [Methodology of Public Administration] Entsyklopediia derzhavnoho upravlinnia [Encyclopedia of Public Administration] (Vol. 2). Kyiv: NADU.

Tymoshchuk, V. (2015). Nadannia administratyvnykh posluh u munitsypalnomu sektori. [ Provision of administrative services in the municipal sector.] (Navchalnyi posibnyk dlia posadovykh osib mistsevoho samovriaduvannia) (ed. Tymoshchuk V.). Asotsiatsiia mist Ukrainy [Association of Ukrainian Cities]. Kyiv: VI EN EI.

Volkova, V. N., Denisov, A. A. (2014). Teoriya sistem i sistemnyy analiz [Theory of systems and system analysis], no. 2. Moskva: Yurayt. 